\title{
HUBUNGAN KONSUMSI ZAT GIZI MIKRO DAN POLA MAKAN DENGAN KEJADIAN OBESITAS
}

\author{
Vina Novela \\ Prodi Kesehatan Masyarakat Universitas Fort De Kock \\ Email: vinanovela7271@gmail.com
}

Submitted: 05-11-2019, Reviewer: 25-11-2019, Accepted: 05-12-2019

\begin{abstract}
Based on the results of Riskesdas West Sumatra, in the age group > 18 of 2013 the prevalence of obesity is 13.5\%. The city of Padang Panjang became the first position to be obese with a percentage of $25.7 \%$. Obesity is a form of obesity that has the strongest relationship with metabolic syndrome. This study aims to determine the relationship of macro nutrient intake, and diet with the incidence of obesity in the organizational unit of the Padang Panjang Barat employee in Padang Panjang. This study uses a cross sectional design. Research location in West Padang Panjang. The number of research respondents was 72 respondents. Respondents who are obese are $51.4 \%$. Macro nutrient intake for carbohydrate intake (63.9\%), protein intake (63.9\%), fat intake (79.2\%), and poor diet (59.7\%). There is a significant relationship between carbohydrate intake and obesity ( $p$ value = $0.017)$ OR $=3.838$, protein with obesity ( $p$ value $=0.001)$ OR $=5.100$, fat with obesity ( $p$ value $=$ $0.002) O R=6.889$, diet with obesity $(p$ value $=0.027)$ OR $=3.399$. Based on the research results, the most risky variable is fat intake, therefore it is recommended that respondents achieve BMI according to standards by consuming intake as needed and controlling diet by reducing consumption of sweet and fried foods and increasing physical activity.
\end{abstract}

Keywords $\quad$ : Carbohydrates, Fats, Diet, Protein.

\begin{abstract}
ABSTRAK
Berdasarkan hasil Riskesdas Sumatera Barat, pada kelompok umur> 18 Tahun 2013 Prevalensi obesitas 13,5\%. Kota Padang Panjang menjadi posisi pertama obesitas dengan persentase $25,7 \%$. Obesitas adalah suatu bentuk obesitas yang memiliki hubungan terkuat dengan sindrom metabolik. Penelitian ini bertujuan untuk mengetahui hubungan asupan gizi makro, dan pola makan dengan kejadian obesitas di kesatuan organisasi karyawan Padang Panjang Barat di Padang Panjang. Penelitian ini menggunakan desain cross sectional. Lokasi penelitian di Padang Panjang Barat. Jumlah responden penelitian adalah 72 responden. Responden yang mengalami obesitas adalah 51,4\%. Asupan nutrisi makro untuk asupan karbohidrat (63,9\%), asupan protein (63,9\%), asupan lemak $(79,2 \%)$, dan pola makan tidak baik $(59,7 \%)$. Ada hubungan yang signifikan antara asupan karbohidrat dan obesitas (nilai $\mathrm{p}=0,017$ ) $\mathrm{OR}=3,838$, protein dengan obesitas (nilai $\mathrm{p}=0,001$ ) $\mathrm{OR}=$ 5,100 , lemak dengan obesitas (nilai $\mathrm{p}=0,002$ ) $\mathrm{OR}=6,889$, pola makan dengan obesitas (nilai $\mathrm{p}=$ $0,027) \mathrm{OR}=3,399$. Berdasarkan hasil penelitian variabel yang paling berisiko adalah asupan lemak untuk itu disarankan responden unutk mencapai BMI sesuai standar dengan mengonsumsi asupan sesuai kebutuhan dan mengendalikan diet dengan mengurangi konsumsi makanan manis dan gorengan serta meningkatkan aktivitas fisik.
\end{abstract}

\section{Kata Kunci : Karbohidrat, Lemak, Diet, Protein}

\section{PENDAHULUAN}

Dalam sepuluh tahun terakhir, obesitas menjadi masalah global (WHO,2015). Obesitas didefinisikan sebagai kondisi abnormal atau kelebihan berat badan lemak yang serius dalam jaringan adipose sedemikian sehingga mengganggu kesehatan. Obesitas adalah kelebihan berat badan sebagai akibat dari penimbunan lemak tubuh yang 
berlebiahan (DR. Merryana \&Bambang ,2012, p.120).

Menurut World Health Organization (WHO), Pada 2016, lebih dari 1,9 miliar orang dewasa berusia 18 tahun ke atas mengalami kelebihan berat badan. Dari jumlah tersebut, lebih dari 650 juta orang dewasa mengalami obesitas.Pada 2016, sebanyak 39\% orang dewasa berusia 18 tahun ke atas (39\% pria dan $40 \%$ wanita) kelebihan berat badan.Secara keseluruhan, sekitar $13 \%$ populasi orang dewasa di dunia (11\% pria dan $15 \%$ wanita) mengalami obesitas pada tahun 2016.Kelebihan berat badan dan obesitas terkait dengan lebih banyak kematian di seluruh dunia daripada kekurangan berat badan.Di Indonesia, prevalensi obesitas menunjukkan angka yang cukup mengkhawatirkan. Menurut Riset Kesehatan Dasar, prevalensi obesitas pada penduduk dewasa usia diatas 18 tahun adalah sebesar $11,7 \%$ pada tahun 2007 dan naik menjadi $15.4 \%$ di tahun 2013. Prevalensi obesitas berbeda menurut jenis kelamin, pada laki-laki adalah 7,8\% pada tahun 2007 dan naik menjadi $19.7 \%$ di tahun 2013 dan pada perempuan adalah $13.9 \%$ di tahun 2007 dan naik menjadi 32.9\% di tahun 2013.

Gambaran Obesitas di Sumatra Barat dapat dilihat dari Riset Kesehatan Dasar (RISKESDAS) Daerah Provinsi Sumatra Barat , kelompok Usia 18 Tahun keatas prvalensi Obesitas berdasarkan Indeks Masa Tubuh (IMT) tahun 2013 Sebesar 10,1\% berat badan lebih dan $13,5 \%$ obesitas. Obesitas cendrung meningkat pada populasi dewasa. Sekitar 8090\% kasus obesitas diperkirakan ditemukan pada rentang usia dewasa. (RI, 2013).

Kota Padang Panjang menduduki posisi pertama kasus obesitas menurut kategori IMT (Indeks Masa Tubuh) dan Kabupaten atau Kota Provinsi Sumatera Barat dengan persentase $25,7 \%$. Berdasarkan karakteristik pendidikan, untuk prevalensi status gizi penduduk usia dewasa (> 18 tahun) dengan pendidikan SLTA memiliki persentasi 14,3\% yang mengami obesitas dan tamatan D1D3/PT 18,5\%. Berdasakan karakteristik tempat tinggal, penduduk yang mengalami obesitas pada daerah perkotaan $15,9 \%$ sedangkan di pedesaan 11,9\% (Riset Kesehatan Dasar Sumbar Tahun 2013). Bila dilihat menurut jenis pekerjaan, Pegawai menempati urutan pertama karakteristik penderita obesitas dengan prvalensi tertinggi sebesar $18.2 \%$.

Secara spesifik tampak bahwa konsumsi makanan terutama golongan sayur dan buah kebanyakan tergolong kurang. Sayur dan buah merupakan golongan makanan sebagai sumber vitamin dan mineral, yang sangat penting bagi kesehatan terutama bagi orang dewasa dan usia lanjut. Pola makan yang tidak teratur akan menjadi pemicu utama munculnya perubahan konsumsi makanan yang tidak sehat. Seseorang yang makannya tidak stabil dan tidak menggunakan aturan makan akan rentan terkena perubahan pola makan ke arah yang buruk. Tidak teraturnya pola makan yang menyebabkan pola makan yang arah yang tidak sehat ini sebenarnya terkait dengan pergeseran gaya hidup atau situasi sosial ekonomi sebuah kelompok masyarakat atau keluarga. Padahal, pola makan tersebut merupakan sumber penyakit (Jafar, 2012,p. 25).

Upaya paling baik untuk mengurangi kasus penyakit degeneratif adalah melalui upaya pencegahan.Pencegahan yang paling baik adalah dengan merubah faktor risiko utama penyebab penyakit degeneratif, yaitu dengan memperbaiki pola makan dan meningkatkan aktifitas fisik. Faktor risiko ini meningkat seiring dengan perubahan gaya hidup seperti kebiasaan makan masyarakat kearah konsumsi makanan tinggi lemak dan gula dan jenis pekerjaan yang tidak banyak mengeluarkan tenaga (sedentary) (kesehatan, 2017).

Berdasarkan penelitian pendahuluan yang telah peneliti lakukan di OPD Kecamatan Padang Panjang Barat dari 78 pegawai, sebagian dari pegawai mengakui lebih menyukai membeli makanan yang telah siap saji atau makanan yang telah dimasak dari pada memasak bahan makanan menjadi makanan. Hal itu dikarenakan waktu untuk berbelanja membeli bahan makanan di pasar dan waktu untuk mengolah bahan makanan tersebut sangat terbatas. Dan hampir seluruh pegawai memiliki pola makan yang tidak baik seperti sarapan tidak pada jam sarapan yang dianjurkan, mengkonsumsi makanan yang tinggi lemak seperti makanan yang bersantan dan digoreng dan jam makan yang tidak teratur.Berdasarkan uraian diatas, peneliti tertarik untuk melakukan penelitian mengenai hubungan asupan zat gizi makro (karbohidrat, 
protein dan lemak), konsumsi serat dan pola makan dengan kejadian obesitas pada pegawai OPD Kecamatan Padang Panjang Barat Kota Padang Panjang Tahun 2018.

\section{METODE PENELITIAN}

Jenis Penelitian yang digunakan adalah survey analitik dengan pendekatan cross sectional study. Sampel padapenelitian ini adalah pegawai di kecamatan Padang Panjang Baratyaitu sebanyak 72 pegawai. Analisis yang digunakan yaitu analisis univariat dan bivariat dengan menggunakan chi square. Dalam penelitian untuk mendapatkan informasi dari responden menggunakan kuesioner dengan metode wawancara.

\section{HASIL PENELITIAN}

\section{A. HASIL UNIVARIAT}

Berdasarkan Tabel diatas $48,6 \%$ pegawai mengalami obesitas, asupan karbohidrat tidak lebih 63,9\%, asupan protein tidak lebih $63,9 \%$ dan asupan lemak tidak lebih $79,2 \%$ dan pola makan tidak baik $59,7 \%$.

\section{B. ANALISIS BIVARIAT}

Hubungan Asupan Zat Gizi
dengan kejadian
pegawai

Berdasarkan tabel 2, diketahui bahwa dari 26 responden yang memiliki asupan karbohidrat lebih, 18 responden $(69,2 \%)$ mengalami obesitas dan 8 responden $(30,8 \%)$ yang tidak mengalami obesitas. Sedangkan dari 46 responden yang memiliki asupan karbohidrat tidak lebih, 17 responden $(37,0 \%)$ yang mengalami obesitas dan 29 responden $(63,0 \%)$ yang tidak mengalami obesitas. Hasil uji statistik menggunakan uji chi-square didapatkan p-value $<0,05 \quad(0,017)$, dapat disimpulkan terdapat hubungan yang bermakna antara asupan karbohidrat responden dengan kejadian obesitas. Hasil analisis juga diperoleh nilai OR (Odd Ratio) $=3,838$ artinya responden yang memiliki asupan karbohidrat berlebih akan berpeluang3,838 kali untuk mengalami obesitas.diketahui bahwa dari 26 responden yang memiliki asupan protein lebih, 20 responden $(76.9 \%)$ mengalami obesitas dan 6 responden $(23,1 \%)$ yang tidak mengalami obesitas. Sedangkan dari 46 responden yang memiliki asupan protein tidak lebih, 15 responden $(32.6 \%)$ yang mengalami obesitas dan 31 responden $(67,4 \%)$ tidak mengalami obesitas. Hasil uji statistik menggunakan uji chi-square didapatkan p-value $<0,05(0,001)$, dapat disimpulkan terdapat hubungan yang bermakna antara asupan protein responden dengan kejadian obesitas. Hasil analisis juga diperoleh nilai OR $($ Odd Ratio) $=6,889$

\begin{tabular}{|c|c|c|}
\hline Kategoti & $\mathbf{f}$ & $\%$ \\
\hline \multicolumn{3}{|l|}{ Obesitas } \\
\hline Obesitas & 35 & 48,6 \\
\hline Tidak Obesitas & 37 & 51,4 \\
\hline \multicolumn{3}{|l|}{ Zat Gizi Makro } \\
\hline Lebih & 26 & 36,1 \\
\hline Tidak Lebih & 46 & 63,9 \\
\hline \multicolumn{3}{|l|}{ Asupan Protein } \\
\hline Lebih & 26 & 36,1 \\
\hline Tidak Lebih & 46 & 63,9 \\
\hline \multicolumn{3}{|l|}{ Asupan Lemak } \\
\hline Lebih & 15 & 20.8 \\
\hline Tidak Lebih & 57 & 79.2 \\
\hline \multicolumn{3}{|l|}{ Pola Makan } \\
\hline Tidak baik & 43 & 59,7 \\
\hline Cukup baik & 29 & 40,3 \\
\hline Total & 72 & 100 \\
\hline
\end{tabular}


Tabel 2. Hubungan Asupan Zat Gizi Makro dengan kejadian obesitas pada pegawai

\begin{tabular}{|c|c|c|c|c|c|c|c|c|}
\hline \multirow{3}{*}{ Kategori } & \multicolumn{4}{|c|}{ Obesitas } & & & \multirow{3}{*}{ P value } & \multirow{3}{*}{$\begin{array}{c}\text { OR } \\
\text { (CI 95\%) }\end{array}$} \\
\hline & \multicolumn{2}{|c|}{ Obesitas } & \multicolumn{2}{|c|}{$\begin{array}{c}\text { Tidak } \\
\text { Obesitas }\end{array}$} & \multicolumn{2}{|c|}{ Total } & & \\
\hline & $\mathbf{n}$ & $\%$ & $\mathbf{n}$ & $\%$ & $\mathbf{n}$ & $\%$ & & \\
\hline \multicolumn{9}{|c|}{ Asupan Karbohirat } \\
\hline Lebih & 18 & 69,2 & 8 & 30,8 & 26 & 100 & \multirow[b]{2}{*}{0,017} & 3,838 \\
\hline Tidak Lebih & 17 & 37,0 & 29 & 63,0 & 46 & 100 & & $\begin{array}{l}(1,376- \\
10,705)\end{array}$ \\
\hline \multicolumn{9}{|c|}{ Asupan Protein } \\
\hline Lebih & 20 & 76.9 & 6 & 23.1 & 26 & 100 & \multirow[t]{2}{*}{0,001} & 6,889 \\
\hline Tidak Lebih & 15 & 32,6 & 31 & 67,4 & 46 & 100 & & $\begin{array}{l}(2,291- \\
20,717)\end{array}$ \\
\hline \multicolumn{9}{|c|}{ Asupan Lemak } \\
\hline Lebih & 13 & 86.7 & 2 & 13.3 & 15 & 100 & \multirow[t]{2}{*}{0,002} & 10,341 \\
\hline Tidak Lebih & 22 & 38,6 & 35 & 61,4 & 57 & 100 & & $\begin{array}{l}(2,127- \\
50,271)\end{array}$ \\
\hline
\end{tabular}

Tabel 3 . Hubungan Pola Makandengan kejadian obesitas pada pegawai Obesitas

\begin{tabular}{|c|c|c|c|c|c|c|c|c|}
\hline \multirow{3}{*}{ Pola Makan } & & \multirow{2}{*}{\multicolumn{2}{|c|}{ Total }} & \multirow{3}{*}{$\begin{array}{c}\mathbf{P} \\
\text { value }\end{array}$} & \multirow{3}{*}{$\begin{array}{c}\text { OR } \\
(\mathrm{CI} \\
\mathbf{9 5 \%})\end{array}$} \\
\hline & \multicolumn{2}{|c|}{ Obesitas } & \multicolumn{2}{|c|}{$\begin{array}{c}\text { Tidak } \\
\text { Obesitas } \\
\end{array}$} & & & & \\
\hline & $\mathbf{n}$ & $\%$ & $\mathbf{n}$ & $\%$ & $\mathbf{n}$ & $\%$ & & \\
\hline Lebih & 26 & 60,5 & 17 & 39,5 & 43 & 100 & & \\
\hline Tidak Lebih & 9 & 31,0 & 20 & 69,0 & 29 & 100 & 0,027 & $\begin{array}{r}3,399 \\
(1,255-\end{array}$ \\
\hline Jumlah & 35 & 48.6 & 37 & 51,4 & 72 & 100 & & $9,205)$ \\
\hline
\end{tabular}

artinya responden yang memiliki asupan protein berlebihakan berpeluang 6,889 kali untuk mengalami obesitas dan bahwa dari 15 responden yang memiliki asupan lemak lebih, 13 responden $(86.7 \%)$ mengalami obesitas dan 2 responden $(13,3 \%)$ yang tidak mengalami obesitas. Sedangkan dari 57 orang responden yang memiliki asupan lemak tidak lebih, 22 responden $(38.6 \%)$ yang mengalami obesitas dan 35 responden $(61,4 \%)$ yang tidak mengalami obesitas. Hasil uji statistik menggunakan uji chi-square didapatkan p-value $<0,05 \quad(0,002)$, dapat disimpulkan terdapat hubungan yang bermakna antara asupan lemak responden dengan kejadian obesitas. Hasil analisis juga diperoleh nilai OR (Odd Ratio) $=10,341$ artinya responden yang memiliki asupan lemak berlebihakan berpeluang 10,341 kali untuk mengalami obesitas.

$\begin{array}{lcr}\begin{array}{l}\text { Hubungan } \\ \text { kejadian }\end{array} & \begin{array}{c}\text { Pola makan } \\ \text { obesitas }\end{array} & \begin{array}{r}\text { dengan } \\ \text { pada }\end{array} \\ \text { pegawai } & & \end{array}$
dari 43 responden yang memiliki pola makan lebih, 26 responden (60.5\%) mengalami obesitas dan 17 responden $(39,5 \%)$ tidak mengalami obesitas. Sedangkan dari 29 responden yang memiliki asupan pola makan tidak lebih, 9 responden $(31,0 \%)$ yang mengalami obesitas dan 20 responden $(69,0 \%)$ tidak mengalami obesitas. Hasil uji statistik menggunakan uji chi-square didapatkan p-value $<0,05(0,027)$, dapat disimpulkan terdapat hubungan yang bermakna 
antarapola makanresponden dengan kejadian obesitas. Hasil analisis juga diperoleh nilai OR $($ Odd Ratio $)=3,399$ artinya responden yang memiliki pola makan yang kurangakan berpeluang 3,399 kali untuk mengalami obesitas.

\section{PEMBAHASAN}

\section{Kejadian Obesitas}

Obesitas merupakan penumpukan lemak yang berlebih di dalam tubuh sehingga membuat berat badan di atas normal.Menurut Adriani dan Wirjatmadi (2014) obesitas sering didefinisikan sebagai kondisi abnormal atau kelebihan lemak yang serius dalam jaringan adiposa sehingga dapat mengganggu kesehatan.

Berdasarkan jenis kelamin pegawai di OPD Kecamatan Padang Panjang Barat, yang paling banyak mengalami obesitas adalah perempuan $(51,3 \%)$. Hasil ini didukung dengan penelitian Winne,dkk tahun 2013 dimana prevalensi Obesitas pada Pegawai Negri Sipil di Sekretariat Jendral Kementrian Kesehatan Republik Indonesia banyak terjadi pada perempuan $(46,5 \%)$. Obesitas pada wanita disebabkan oleh pengaruh faktor endokrin, karena kondisi ini muncul pada saat-saat adanya perubahan hormonal. Pada pria, rata-rata lemak tubuhnya adalah $12 \%$ sedangkan pada wanita sekitar $26 \%$

Di OPD Kecamatan Padang Panjang Barat, peneliti melihat responden perempuan memiliki resiko obesitas yang tinggi karena pola makan yang salah. Hal ini dilihat dari sering makan makanan ringan seperti keripik, kue atau biskuit saat bekerja, sering membeli makanan dari rumah makan karena responden mengeluh tidak memiliki waktu untuk memasak atau mengolah makanan sendiri di rumah.

\section{Asupan Zat Gizi Makro}

a. Asupan Karbohidrat

Karbohidrat memiliki fungsi utama, yaitu sebagai penyedia energi bagi tubuh. dalam tubuh seseorang, sebagian karbohidrat berada pada sirkulasi darah dalam bentuk glukosa, sebagian pada hati dan jaringan otot dalam bentuk glikogen, dan sebagian diubah menjadi lemak untuk disimpan sebagai cadangan energi di dalam jaringan lemak (Almatsier,2009).
Penelitian Stephanie tahun 2012 yang dilakukan pada wanita usia subur di kecamatan Singkil Manado, juga mendapatkan hasilbahwa asupan karbohidrat kurang pada subjek penelitian adalah sebanyak $62.34 \%$ atau 48 responden. Dan penelitian ini tidak sejalan dengan penelitian yang dilakukan oleh Wegiarti dkk Tahun 2017 yang menyatakan bahwa $85,7 \%$ responden memiliki asupan karbohidrat yang normal.(sikalak, 2017)

Menurut peneliti, kebiasaan mengkonsumsi nasi (beras putih biasa) dan makanan olahan tepung terigu seperti mie yang sering dikonsumsi oleh responden sangat beresiko timbulnya obesitas.Mie dan nasi adalah makanan yang banyak ditemui di Padang Panjang. Mi instan dan nasi berasal dari biji-bijian olahan.Keduanya sama-sama berfungsi sebagai sumber karbohidrat.

\section{b. Asupan Protein}

Protein merupakan zat gizi dasar yang berguna dalam pembentukan protoplasma sel. Protein mempunyai fungsi khas yang tidak dapat digantikan oleh zat gizi lain yaitu membangun serta memelihara selsel dan jaringan tubuh (Almatsier,2009). Kebutuhan Protein pada usai dewasa adalah 50-60 gram per hari atau berkisar $11 \%$ dari total masukan energy (Merryana \& Bambang, 2012, p.366).

Penelitian yang dilakukan oleh Nadia loliana menunjukkan hasil bahwa ratarata asupan energi remaja obesitas lebih tinggi jika dibandingkan dengan kelompok remaja non obesitas Sebesar 34,8\% remaja obesitas memiliki tingkat kecukupan energi lebih, sedangkan pada remaja non obesitas hanya $13,0 \%$ yang memiliki tingkat kecukupan energi lebih Hasil tersebut menunjukkan bahwa asupan energi pada remaja kelompok obesitas lebih besar dari pada asupan energi pada remaja kelompok non obesitas.(Loliana, 2015)

Hasil data asupan, dapat diketahui makanan sumber protein yang sering dikonsumsi pegawai adalah telur yang dikonsumsi pada saat sarapan dalam bentuk teh telur, daging ayam dan ikan segar. Jenis bahan makanan yang sering 
dikonsumsi oleh responden dikarenakan jenis bahan makanan tersebut mudah didapat di kota Padang panjang. Dan sebaiknya dalam mengkonsumsi bahan makanan yang mengandung protein, responden dapat memperhatikan kandungan protein dalam bahan makanan tersebut yang dapat dilihat dari daftar komposisi bahan makanan atau membaca label makanan pada kemasan.

\section{c. Asupan Lemak}

Lemak memiliki nilai energi lebih tinggi bila dibandingkan dengan hidrat arang, protein ataupun alcohol.Lemak merupakan bentuk energi yang paling pekat dalam makanan, sehingga dengan mengurangi konsumsi lemak akan mengurangi pula kandungan energi dalam makanan (Marry E, 2000). Lemak juga dapat memberikan tenaga bagi tubuh, bila asupan lemak berlebihan, kalori yang tidak terpakai akan ditimbun dalam tubuh. Lemak merupakan bentuk energi yang paling pekat dalam makanan, sehingga dengan mengurangi konsumsi lemak akan mengurangi pula kandungan energi dalam makanan (Nasedul,2008).

Rata-rata pegawai mengkonsumsi jenis asam lemak jenuh seperti lemak pada bahan makanan hewani. Lemak nabati yang sering dikonsumsi berasal dari minyak kelapa sawit, santan, dan lemak hewani seperti telur ayam,daging ayam, dan ikan segar. Kelebihan asupan lemak dapat disebabkan oleh konsumsi gorengan, kue manis, makanan bersantan dan berminyak yang cukup tinggi. Konsumsi minyak dibatasi sebanyak 5 sendok makanan makan perhari. Menurut peneliti, responden yang memiliki asupan lemak yang lebih juga disebabkan oleh seringnya mengkonsumsi makanan yang menggunakan santan dalam pengolahannya, seperti gulai ikan, rendang, kalio daging dan gulai ayam.Hal ini juga dapat dilihat dari hasil wawancara, rata-rata responden memiliki frekuensi mengkonsumsi makanan bersantan 3-4 kali perminggu.Dan juga karena kesibukan responden yang merupakan seorang pegawai, sering membeli makanan yang dibeli di rumah makan atau makanan yang siap saji yang banyak mengandung lemak dari minyak dan santan.

3. Pola Makan

Orang yang kegemukan lebih esponsif dibanding dengan orang berberat badan normal terhadap isyarat lapar eksternal, seperti rasa dan bau makanan, atau saatnya waktu makan. Orang yang gemuk cendrung makan bila ia merasa ingin makan, bukan makan pada saat lapar. Pola makan berlebihan inilah yang menyebabkan mereka sulit untuk keluar dari kegemukan jika sang individu tidak memiliki kontrol diri dan motivasi yang kuat untuk mengurangi berat badan ( Hasdianan, 2014, p. 72).

Berdasarkan hasil data pola makan, pola makan setiap responden berbedabeda. Rata-rata responden memiliki pola makan yang cukup pada golongan makan pokok dan protein hewani. Hal ini dikarenakan setiap sekali makan, responden lebih membutuhkan nasi dan lauk dari pada mengkonsumsi tahu, tempe, sayur sayuran dan ditambah dengan buah. Dari hasil wawancara juga didapatkan, responden mengaku kurang mengkonsumsi jenis sayur-sayuran dikarenakan responden mengalami penyaki asam urat.

\section{B. Analisis Bivariat}

\section{Hubungan Asupan Karbohidrat dengan Kejadian Obesitas}

Kesalahan makan yang lazim terdapat pada masyarakat modern adalah mengkonsumsi terlampau banyak karbohidrat dalam bentuk yang sudah dimurnikan. Untuk fungsi usus yang normal diperlukan serat yang tidak dapat dicerna dan ada dalam biji-bijian yang utuh, misalnya beras tumbuh, havermout, jagung dan lain-lain. Masukan karbohidrat yang berlebih biasanya berarti masukan gula yang tinggi. Kalau masukan ini melampaui kebutuhan tubuh akanenergy, maka akan terjadi hidratarang yang berlebih itu menjadi lemak sehingga menimbulkan obesitas (Marry E.Beck, 2000, p. 12).

Makanan sumber karbohidrat yang sering dikonsumsi pegawai di OPD Kecamatan Padang Panjang Barat Kota 
Padang Panjang terdiri dari karbohidrat kompleks dan karbohidrat sederhana. Makanan sumber karbohidrat kompleks yang sering dikonsumsi adalah adalah nasi beras putih, jagung, mie kering dan singkong. Sedangkan untuk makanan sumber karbohidrat sederhana yang sering dikonsumsi adalah gula pasir dalam teh, kopi dan Teh Telur yang sering dikonsumsi pegawai pada saat sarapan.

Penelitian ini juga didukung oleh penelitian miftahul dimana adanya perbedaan yang signifikan asupan zat gizi makro (protein, lemak, dan karbohidrat) dan serat pada pre lansia dengan status gizi normal dan status gizi obesitas. Hasil penelitian menunjukan bahwa rata-rata asupan protein, lemak, karbohidrat dan serat pre lansia dengan status gizi obesitas lebih tinggi dibandingkan dengan asupan pre lansia dengan status gizi normal.(ulum, 2014)

\section{Hubungan Asupan Protein dengan Kejadian Obesitas}

Fungsi utama protein ialah untuk membangun dan memelihara sel - sel, serta jaringan tubuh (Almatsier, 2010).Protein ini merupakan zat gizi yang terbesar kedua yang berada dalam tubuh setelah air.Asupan protein yangtinggi dapat menyebabkan kegemukan dan obesitas (Atmasier, 2010). Dalam keadaan berlebihan, protein akan diubah menjadi lemak dan disimpan di dalam tubuh. Dalam pedoman gizi seimbang, Departemen Kesehatan Republik Indonesia menganjurkan untuk mengonsumsi protein hewani (ikan, daging, ayam, telur, keju, dll) dan protein nabati (sayur-sayuran, kacang-kacangan, tahu, tempe, dll) sebanyak 3-4 porsi per hari (Kemenkes RI, 2015).

Konsumsi makanan pegawai yang tinggi protein dan sering di konsumsi seperti ikan segar, ikan segar air tawar, daging ayam dan telur. Hasil wawancara dengan responden juga didapatkan bahwa renponden sering mengkonsumsi teh telur yang dijual di warung dekat tempat kerja yang dikonsumsi dengan frekuensi 3-4 kali seminggu.Pada hasil analisis juga dapat diketahui dari 46 responden yang memiliki asupan protein tidak lebih, terdapat 15 responden yang mangalami obesitas. Hal ini mungkin dikarenakan jenis bahan makanan lain yang menyebabkan seseorang menjadi obesitas.

\section{Hubungan Asupan Lemak dengan Kejadian Obesitas}

Lemak dan minyak merupakan sumber energi paling padat, dimana 1 gram lemak menghasilkan 9 kilokalori atau $2 \quad 1 / 2$ kali menghasilkan energi lebih besar dibandingkan karbohidrat dan protein. Simpanan lemak didalam tubuh berasal dari asupan lemak yang berlebih atau kombinasi antara zat-zat gizi lain, seperti karbohidrat, dan protein (Almatsier,2009).

Berdasarkan hasil data asupan, dapat diketahui makanan sumber lemak yang sering dikonsumsi pegawai dari sumber lemak hewani adalah minyak kelapa sawit, ayam, telur ayam dan dari sumber lemak nabati adalah santan. Dilihat dari cara pengolahan bahan makanan, pegawai lebih sering mengkonsumsi makanan dengan cara pengolahan digoreng dan bersantan daripada dengan cara pengolahan direbus, diungkap, dibakar atau dipanggang. Rata-rata dalam seminggu pegawai mengkonsumsi makanan bergoreng sebanyak 4-5 kali dan yang bersantan sebanyak 2-3 kali seminggu. konsumsi makanan berlemak berperan dalam peningkatan lemak tubuh karena densitas energi yang tinggi, efek rasa lezat makanan berlemak, tingginya efisiensi metabolik, lemahnya kekuatan rasa kenyang, lemahnya regulasi fisiologi asupan lemak terhadap asupan karbohidrat.

\section{Hubungan Pola Makan dengan Kejadian Obesitas}

Makanan merupakan kebutuhan mendasar bagi setiap manusia, makanan yang dikonsumsi berbagai jenis dengan berbagai cara pengolahannya. Pada masyarakat dikenal pola makan dan kebiasaan makan dimana seseorang atau sekelompok orang tinggal. Pola makan merupakan gambaran apa yang dimakan seseorang maupun masyarakat tertentu baik dari jenis, jumlah dan frekuensi makanan. Faktor-faktor yang mempengaruhi konsumsi pangan adalah faktor ekonomi dan harga serta faktor sosio budaya dan religi (Merryana, 2012).

Berdasarkan hasil data asupan, dapat diketahui makanan sumber lemak yang sering dikonsumsi pegawai dari sumber lemak 
hewani adalah minyak kelapa sawit, ayam, telur ayam dan dari sumber lemak nabati adalah santan. Dilihat dari cara pengolahan bahan makanan, pegawai lebih sering mengkonsumsi makanan dengan cara pengolahan digoreng dan bersantan daripada dengan cara pengolahan direbus, diungkap, dibakar atau dipanggang. Rata-rata dalam seminggu pegawai mengkonsumsi makanan bergoreng sebanyak 4-5 kali dan yang bersantan sebanyak 2-3 kali seminggu.

Kebiasaan pegawai di OPD Kecamatan Padang Panjang Barat sering konsumsi minuman yang manis seperti kopi, teh manis, dan minuman kopi instan pada saat bekerja. Sebaiknya kebiasaan tersebut di kurangi karena banyak kerugian yang ditimbulkan daripada manfaat yang diberikan oleh minumanmanis. Hal ini dapat menjadi pemicuobesitas, mengakibatkan lonjakan gula darah yang bisa memicu diabetes. Selain itu, pegawai di OPD Kecamatan Padang Panjang Barat kota Padang Panjang juga sering menkonsumsi teh telur setelah makan pada saat sarapan di kantin atau warung yang ada di sekitar kantor.

Sesuai hasil penelitian yang dilakukan oleh yulia kurniawati diketahui bahwa ada hubungan antara pola makan, aktivitas fisik, dan durasi tidur dengan kejadian obesitas ( $\mathrm{p}$ value $=0,047 ; p$-value $=0,0001 ;$ pvalue $=0,009)$ dan tidak ada hubungan antara asupan energi dengan kejadian obesitas ( $\mathrm{p}$-value $=0,333$ ) (kurniawati, 2016)

\section{KESIMPULAN}

Berdasarkan hasil penelitian faktor yang paling berhubungan dengan kejadian obesitas adalah asupan zat gizi mikro pegawai terutama asupan lemak dan protein, untuk itu diharapkan pegawai yang mengalamiobesitas dapat mengkonsumsi asupan sesuai kebutuhan, mengontrol pola makan. pengolahan makanan dengan menggunakan sedikit minyak atau lemak seperti ditumis, disetup, direbus, dikukus atau di bakar. Lebih memperhatikan budaya pola makan yang salah seperti konsumsi teh telur dan gorengan.

UCAPAN TERIMA KASIH
Ucapan terima kasih penulis sampaikan terutama kepada responden yang telah membantu selesainya penelitian ini, peneliti juga mengucapkan terimakasih kepada Kantor camat padang panjang barat yang telah memfasilitasi dalam pelaksanaan penelitian.

\section{DAFTAR PUSTAKA}

Andriani, Merryana. Wirjatmadi, Bambang. 2012. PengantarGiziMasyarakat. PT FajarInterpratamaMandiri. Jakarta.

BadanPusatStatistik. 2016., Kota Padang PanjangdalamAngka. BadanPusat Statistik Kota Padang Panjang.

Beck,Mary E. 2000. Ilmu Gizi dan Diet, Hubungannya dengan Penyakit-P enyakit untuk Perawat dan Dokter. Yayasan Essentia Medica (YEM). Yogyakarta.

Dinas Kesehatan Kota Padang Panjang. Rekapitulasi LaporanPenyakitTidak Menular (PTM) BulanJanuari-Oktober 2017.

Elya Sugianti. Faktorrisiko obesitassentral pada orang dewasa di Sulawesi, Gorontalo dan DKI Jakarta [JurnalPenelitian]. [Bogor]: Institut Pertanian Bogor; 2009.

Hasdianah.Siyoto, Sandu.Peristyowati. 2014. Gizi: PemanfaatanGizi, Diet dan Obesitas. Nuha Medika. Yogyakarta.

Irianto, Djoko Pekik. 2007. Pedoman Gizi Lengkap: Keluarga dan Olahragawan. Andi Offset. Yogyakarta.

Irwan. 2016. Epidemiologi Penyakit Tidak Menular. Deepublish Budi Utama. Yogyakarta.

Kementrian Kesehatan Republik Indonesia. 2004. Angka Kecukupan Gizi. Jakarta.

Kurniawati, Y. (2016). HUBUNGAN ANTARA POLA MAKAN, ASUPAN ENERGI, AKTIVITAS FISIK, DAN DURASI TIDUR DENGAN KEJADIAN OBESITAS PADA POLISI . Jurnal Publikasi Kesehatan Masyarakat Indonesia, Vol.3 No.3, , 112-117. 
Kesehatan, K. (2017). Buku Rencana Aksi Nasional Pencegahan Dan Pengendalian Penyakit Tidak Menular 2015-2019. Indonesia: Kementrian Kesehatan RI.

Loliana, N. (2015). ASUPAN DAN KECUKUPAN GIZI ANTARA REMAJA OBESITAS DENGAN NON OBESITAS. Media Gizi Indonesia , 10(2), 141-145.

Loliana, N. (2015). ASUPAN DAN KECUKUPAN GIZI ANTARA REMAJA OBESITAS DENGAN NON OBESITAS. Media Gizi Indonesia, 10(2), 141-145.
RI, B. P. (2013). Laporan Hasil Riset Kesehatan Dasar (RISKESDAS). Indonesia: Kementrian Kesehatan RI.

Sikalak, W. (2017). Faktor-Faktor Yang Berhubungan Dengan Kejadian Obesitas Pada Karyawan Perusahaan Di Bidang . JURNAL KESEHATAN MASYARAKAT (E-Journal) UNDIP, 193-201.

Ulum, M. (2014). ANALISIS ASUPAN ZAT GIZI MAKRO, SERAT DAN OBESITAS PADA PRE LANSIA USIA 45-54 TAHUN DI WILAYAH JAWA DAN BALI (ANALISIS DATA RISKESDAS 2010) . Nutrire Diaita Volume 6 Nomor 1, April 2014, 6-13. 